\title{
Correlation between the ibopamine provocative test and the diurnal tension curve in glaucoma patients
}

\author{
Correlação entre o teste provocativo da ibopamina e a curva diurna \\ de pressão intra-ocular em pacientes com glaucoma
}

\author{
Leopoldo Magacho ${ }^{1}$ \\ Marcelus Layguel Costa ${ }^{2}$. \\ Ricardo Reis ${ }^{3}$ \\ Neuza Rios ${ }^{4}$ \\ Marcos Pereira de Ávila 5
}

\begin{tabular}{l} 
ABSTRACT \\
\hline Purpose: To correlate the ibopamine provocative test with the diurnal \\
tension curve (highest intraocular pressure-IOP and range) in glaucoma. \\
Methods: This is a prospective case series including glaucoma patients \\
fromtheFederal University of Goiás, Glaucoma Service. Two $2 \%$ ibopamine \\
eyedrops were instilled into one or both eyes of each patient, 5 minutes \\
apart. Intraocular pressure was checked before and 30 and 45 minutes \\
after the second ibopamine instillation. Thereafter, the diurnal tension \\
curve of each patient was assessed with five independent measurements \\
(atevery 2:30 hours), from 8:00o'clock AM to 6:00 o'clock PM. Pearson's \\
correlation coefficient was used to test the linear relation between the \\
intraocular pressure after the ibopamine instillation with the highest \\
intraocular pressure value and the intraocular pressure range in the \\
diurnal curve. Results: Thirty-one eyes from 22 patients were included. \\
There was a significant correlation between the intraocular pressure 30 \\
and 45 minutes after ibopamine instillation and the highest intraocular \\
pressure assessed in the diurnal curve (r=0.356, p=0.04 and r=0.429, \\
p=0.01, respectively). However, no correlation between IOP after the use \\
of ibopamine and the diurnal intraocular pressure range at 30 (r=0.046, \\
p=0.8) and 45 minutes (r=0.109, p=0.5) was observed. Conclusion: The \\
ibopamine provocative test shows a significant correlation with the \\
highest intraocular pressure in the diurnal tension curve in glaucoma \\
patients. However, no correlation was observed with the intraocular \\
pressure range.
\end{tabular}

Keywords: Glaucoma; Ophthalmic solutions; Intraocular pressure; Dopamine agonists/ diagnostic use; Circadian rhythm; Comparative study

\footnotetext{
${ }^{1}$ Coordenador Acadêmico e do Setor de Glaucoma do Centro de Referência em Oftalmologia (CEROF) da Universidade Federal de Goiás - UFG - Goiânia (GO) Brasil. Doutor em Oftalmologia pela Universidade Estadual de Campinas - UNICAMP - Campinas (SP) - Brasil. ${ }^{2}$ Médico assistente do Setor de Glaucoma do CEROF da UFG - Goiânia (GO) - Brasil.

${ }^{3}$ Responsável pelo Setor de Glaucoma da Santa Casa de Misericórdia de São José do Rio Preto - São José do Rio Preto (SP) - Brasil.

${ }^{4}$ Ex-residente do CEROF da UFG - Goiânia (GO) - Brasil.

${ }^{5}$ Professor Doutor e Chefe do CEROF da UFG - Goiânia (GO) - Brasil

Autor correspondente: Leopoldo Magacho. Rua 131, nº 313 - Setor Sul - Goiânia (GO) CEP 74093-200

E-mail: 1magacho@brturbo.com.br

Recebido para publicação em 27.05.2005

Versão revisada recebida em 29.11.2005

Aprovação em 02.01.2006

Os autores não possuem interesse comercial sobre os produtos citados no texto.
}

\section{INTRODUCTION}

Several provocative tests have been designed to detect glaucoma in its early stages ${ }^{(1-4)}$. However, none of them have proved to be of clinical value.

In the past few years, studies with $2 \%$ ibopamine ophthalmic solution have shown good ability to differentiate normal individuals from glaucoma patients. Ibopamine (N-methyldopamine 3,4 di-isobutyrylester) 2\% eyedrops are hydrolyzed to epinine, a dopamine analogue. Epinine binds to $\alpha$ adrenergic and D-1 dopaminergic receptors. The adrenergic binding causes a non-cycloplegic mydriasis, greater than $10 \%$ phenylephrine and $1 \%$ tropicamide $^{(5)}$, while the D-1 dopaminergic action causes an increase in aqueous humor production ${ }^{(6-7)}$. Because glaucoma patients may have an impaired outflow system, a provocative test has been proposed based on the theory 
that glaucoma eyes would have a greater rise in intraocular pressure (IOP) compared to normal individuals. Several authors have achieved good sensitivity and specificity with the ibopamine provocative test for glaucoma ${ }^{(7-11)}$.

Glaucoma patients typically have larger intraocular pressure fluctuations compared to the normal population ${ }^{(12-14)}$. Therefore, a single IOP measurement may not be able to detect IOP peaks during the day. Patients apparently undergoing progressive visual field loss were found to have significantly more frequent IOP peaks than patients with stable visual fields ${ }^{(15)}$. Furthermore, large diurnal fluctuations are an independent risk factor for glaucoma ${ }^{(16)}$.

Because the diurnal curve demands the entire day to be done, a simple test with good correlation with the IOP variability (IOP range and IOP peak) during the day would be preferable. The purpose of this study is to correlate the ibopamine provocative test with the diurnal tension curve in glaucoma.

\section{METHODS}

This is a prospective case series including glaucoma patients from the Federal University of Goiás, Glaucoma Service. One or both eyes (if eligible) from each patient were consecutively included after written and informed consent.

The inclusion criteria were: primary open-angle glaucoma, (Goldmann applanation tonometry showing IOP $\geq 22$ in at least 2 different examinations; gonioscopy showing an open angle; a glaucomatous optic neuropathy, that is, localized or generalized narrowing of the neuroretinal rim, disc hemorrhage, or cup/disc asymmetry $>0.2$ and at least two reliable ${ }^{(17)}$ SITA Standard Humphrey 24-2 abnormal visual fields.

The exclusion criteria included narrow angles, secondary glaucoma, ocular hypertension or any significant change on slit lamp examination that could interfere with the perimetric examination (i.e: macular degeneration) or with the tonometry (i.e: corneal opacity). We also excluded patients who underwent refractive surgery, using prostaglandin analogues ${ }^{(8)}$, recent history (6 months) of ocular inflammation, functional antiglaucomatous surgery (trabeculectomy, tube shunts), inability to perform any of the examination or refuse to participate in the study. Patients using any antiglaucoma drug for less than 3 months were also excluded.

Two 2\% ibopamine eyedrops were instilled into one or both eyes of each patient, 5 minutes apart. The IOP was checked before, and 30 and 45 minutes after the second ibopamine instillation, always around 9:00 o'clock AM. Thereafter, the diurnal tension curve of each patient was assessed, at least one week later (but no more than one month). Five independent measurements were done (at every 2:30 hours), from 8:00 o'clock AM to 6:00 o' clock PM.

The IOP was the mean of 2 independent and consecutive measurements, always in the same calibrated Goldmann tonometer by the same examiner. A second person read the IOP. If the difference between the first and the second measurements was greater than $2 \mathrm{mmHg}$, a third measurement was made, discarding the most discrepant value.

Statistical analysis was performed with SPSS (SPSS inc., Chicago, IL), version 11.5 software. The Komogorov-Smirnov test was used to assess the normality of each distribution. Pearson's correlation coefficient was used to test the linear relation between IOP after the ibopamine instillation with the highest IOP value and the IOP range (difference between the maximum and the minimum IOP recorded) in the diurnal curve. Paired Student's t test was used to analyze IOP variation before and after ibopamine instillation. The measures of agreement between the variables in the correlation was obtained with the intraclass correlation coefficient. In our study, $\mathrm{p}<0.05$ was considered statistically significant.

\section{RESULTS}

Thirty-one eyes from 22 patients were included in the study. The mean age was $62.5 \pm 10.9$ years, and only 2 men ( 4 eyes) were included. IOP distribution is shown in Table 1. IOP after 30 and 45 minutes after $2 \%$ ibopamine instillation was significantly higher $(p<0.001)$ than baseline IOP. However, there was no noticeable difference between the IOP 30 and 45 minutes $(\mathrm{p}=0.09)$ after $2 \%$ ibopamine instillation. IOP peaks were measured in the morning (8:00 o'clock AM or 10:30 AM) in $93.5 \%$ of patients $(29 / 31)$.

There was a significant correlation between the IOP 30 and 45 minutes (Figure 1) $(\mathrm{r}=0.356, \mathrm{p}=0.04$ and $\mathrm{r}=0.429, \mathrm{p}=0.01$, respectively) and agreement $(\mathrm{p}=0.03$ and $\mathrm{p}=0.01$, respectively) after ibopamine instillation and the highest IOP assessed in the diurnal curve. However, there was no correlation between IOP after the use of ibopamine and the diurnal IOP range at 30 $(\mathrm{r}=0.046, \mathrm{p}=0.8)$ and 45 minutes $(\mathrm{r}=0.109, \mathrm{p}=0.5)$.

\section{DISCUSSION}

Some studies have demonstrated the advantages of IOP reduction in glaucoma patients ${ }^{(18-19)}$, including normal tension

\begin{tabular}{|c|c|c|c|c|c|c|c|}
\hline & $\begin{array}{l}\text { IOP at } \\
\text { baseline }\end{array}$ & $\begin{array}{l}1 O P \text { at } \\
30 \mathrm{~min}\end{array}$ & $\begin{array}{l}\text { IOP at } \\
45 \mathrm{~min}\end{array}$ & $\begin{array}{l}\text { IOP rise } \\
\text { at } 30 \mathrm{~min}\end{array}$ & $\begin{array}{l}\text { IOP rise } \\
\text { at } 45 \mathrm{~min}\end{array}$ & $\begin{array}{l}\text { Highest IOP } \\
\text { in the curve }\end{array}$ & $\begin{array}{l}\text { IOP fluctuation } \\
\text { (higher-lower) }\end{array}$ \\
\hline Mean & 19.1 & 23.6 & 24.5 & 4.5 & 5.4 & 18.8 & 3.8 \\
\hline Standard deviation & 4.1 & 4.1 & 3.9 & 5.1 & 3.7 & 2.8 & 1.8 \\
\hline${ }^{*} \mathrm{mmHg}$ & & & & & & & \\
\hline
\end{tabular}




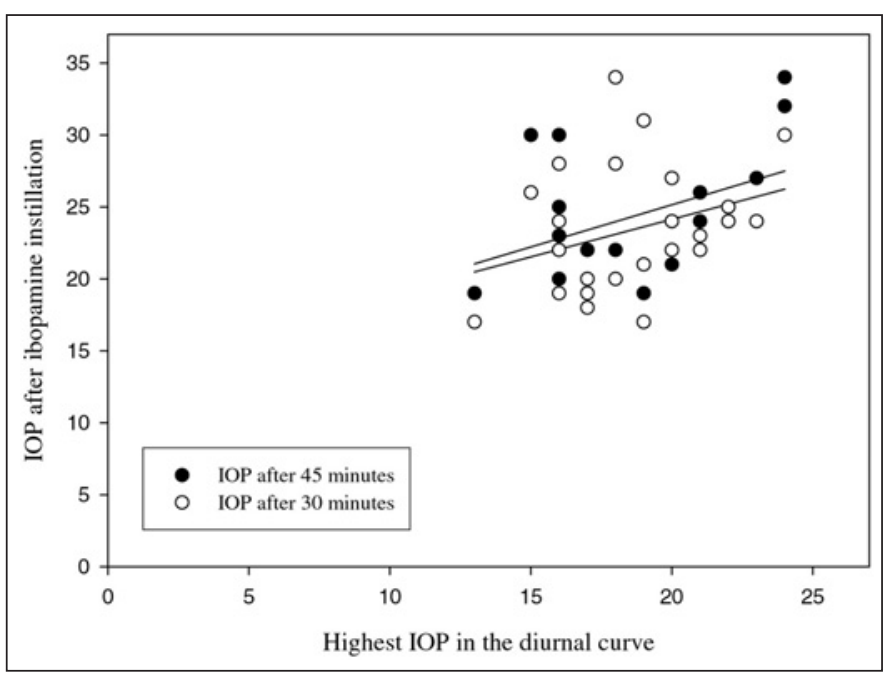

Figure 1 - Scatterplot showing the relation between the highest IOP in the diurnal curve and the IOP after ibopamine instillation

glaucoma $^{(20)}$. In the Advanced Glaucoma Intervention Study (AGIS), almost no visual field deterioration was observed in patients whose IOP was kept on safety and lower levels ${ }^{(18)}$. However, in a certain amount of patients, it is possible to have glaucomatous progression despite apparently controlled IOP. The visual field loss could have occurred at a time when IOP is high, although it was controlled at the time of measurement. It has been suggested that large diurnal fluctuations in $\mathrm{IOP}^{(12-14)}$ may be an additional risk factor in patients with glaucoma ${ }^{(16)}$. Furthermore, IOP peaks may not be recognized in a single office IOP measurement and also be responsible for additional visual field loss despite apparently controlled IOP(15).

Some authors ${ }^{(15)}$ have shown that, in a population with a $30 \%$ prevalence of progressive loss of visual field, $75 \%$ of the patients with peaks have progressive loss and $75 \%$ of those without peaks do not have visual field progression. Another group $^{(16)}$ has found that $29 \%$ of patients with a progressive visual field loss had IOP peaks, compared with $5 \%$ of patients with stable visual fields. In the same study, the IOP range was also considered a strong and independent risk factor in patients with glaucoma. Therefore, the office IOP may not be sufficient to assess the adequacy of treatment. Nevertheless, the diurnal IOP assessment (diurnal tension curve) demands the entire day to be done, what is somehow complicated in busy clinics.

The $2 \%$ ibopamine eyedrops may be used as a provocative test for glaucoma, being easy to perform, and has shown good sensitivity/specificity results ${ }^{(8,11)}$. It is reasonable to hypothesize that a linear association between the ibopamine test and the IOP measurements from the diurnal curve (IOP peaks and IOP range) would give us much more information than a single IOP measurement. Additionally, ibopamine eyedrops cause a non-cycloplegic mydriasis, allowing a comfortable fundus examination for the patient. Furthermore, we would be assessing the efficacy of the patient's treatment during the day, and not only at the time the patient is in the office. For that reason, we decided to include glaucoma patients undergoing medical treatment for glaucoma. However, it was necessary to exclude patients using prostaglandin analogues that seem to reduce the test's sensitivity and the IOP rise ${ }^{(8)}$. This fact limits the test's utility, since the prostaglandin analogues have become the first (or second) line of treatment for the majority of glaucoma specialists. It is possible that the increased aqueous humor production by means of ibopamine instillation is also drained through the uveo-scleral pathway ${ }^{(21)}$.

The baseline IOP at 9:00 o' clock AM $(19.1 \pm 4.1 \mathrm{mmHg})$ before the ibopamine test was slightly higher than the highest IOP in the diurnal curve $(18.8 \pm 2.8 \mathrm{mmHg})$. However, the diurnal IOP was assessed about 1 week after the ibopamine provocative test with no change in the drug administration and always using the same calibrated Goldmann tonometer by the same masked examiner. In the present study, in $93.5 \%$ of the patients (29/31), the IOP peak in the diurnal curve was measured in the morning, close to the baseline IOP measurement, before the ibopamine test. Therefore, we do not think this is an inclusion bias, but only normal fluctuation in IOP that may occur in glaucoma patients ${ }^{(12-14)}$, since the highest IOP during the day was almost coincident with the baseline IOP. Another possible explanation is related to the D-1 dopaminergic ibopamine action $^{(6)}$, which may cause an overresponse in aqueous humor production few minutes after the ibopamine instillation that may fatigue the ciliary muscle receptors for a period of time longer than a couple of weeks. We do not believe that this is possible, since in a previous study, the IOP in glaucoma patients dropped to values close to baseline measurements only 180 minutes after ibopamine use ${ }^{(8)}$.

In the present study, $2 \%$ ibopamine has demonstrated good and similar ability to increase IOP in glaucoma patients, at 30 and 45 minutes after instillation ( $\mathrm{p}<0.001$ at each time). We decided to evaluate the IOP at both timepoints because studies have shown good results with the ibopamine provocative test at $30^{(8)}$ and 45 minutes ${ }^{(7,9)}$ after ibopamine instillation. In the earlier measurement, the cutoff point was set as greater than $4 \mathrm{mmHg}$, while the IOP rise greater than $3 \mathrm{mmHg}$ was used at 45 minutes. We did not analyze the sensitivity and specificity because the performance of the test was not the purpose of the present study.

The IOP after the ibopamine test was significantly correlated with the highest IOP in the diurnal curve at $30(\mathrm{r}=0.356$, $\mathrm{p}=0.04)$ and 45 minutes $(\mathrm{r}=0.429, \mathrm{p}=0.01)$. It means that, the higher the IOP after the ibopamine eyedrops, the higher will be the maximum IOP during the day (from 8:00 o' clock to 18:00 o'clock). Thus, it may be possible to associate high pressures after the ibopamine test with IOP peaks during the day. On the other hand, there was no significant correlation between the ibopamine provocative test and the IOP range, at $30(\mathrm{r}=0.046$, $\mathrm{p}=0.8)$ and 45 minutes $(\mathrm{r}=0.109, \mathrm{p}=0.5)$. It is possible that the use of antiglaucomatous drugs could reduce the IOP range during the day and consequently the correlation between the ibopamine provocative test and the difference between the 
highest and lowest IOP during the day. Patients off treatment could have significant correlation between IOP range and ibopamine test, and even better results testing its association with peaks of IOP in the diurnal tension curve. Because IOP fluctuation and peak within the 24 hours of the day may be larger than that registered in the diurnal tension curve, our results should be interpreted carefully. This is a limitation of the study, and also another potential reason for our results, that could be even better (or completely null) if the 24-hour IOP was evaluated.

There are some interesting reports about the use of $2 \%$ ibopamine eyedrops as an adjunctive test for glaucoma, with good sensitivity/specificity results to differentiate normal individuals from glaucoma patients ${ }^{(7-9)}$. Additionally, the noncycloplegic and large mydriasis ${ }^{(5)}$ allows comfortable fundus examination. We are now suggesting a new application for the ibopamine test by correlating IOP after the test with the highest IOP in the diurnal tension curve. Further studies confirming our results and other potential uses for the ibopamine test in glaucoma are suggested.

\section{CONCLUSION}

The ibopamine provocative test has a significant correlation with the highest IOP in the diurnal tension curve in glaucoma patients. However, no correlation was observed with the IOP range.

\section{RESUMO}

Objetivo: Correlacionar o teste provocativo da ibopamina com a curva diurna de pressão intra-ocular (Pio máxima e flutuação da mesma) em pacientes com glaucoma. Métodos: Estudo prospectivo incluindo pacientes com glaucoma provenientes do CEROF-UFG. Duas gotas de ibopamina a $2 \%$ foram instiladas em um ou ambos os olhos dos pacientes com intervalo de 5 minutos entre elas. A pressão intra-ocular foi checada antes, 30 e 45 minutos após a segunda gota de ibopamina. Após, a curva diurna de pressão intra-ocular foi realizada com 5 medidas independentes (a cada 2:30 horas) entre 8:00 e 18:00 horas. A correlação de Pearson foi utilizada para se testar a relação linear entre a pressão intra-ocular após o uso da ibopamina, a pressão intra-ocular máxima e a flutuação diurna da pressão intra-ocular. Resultados: Trinta e um olhos de 22 pacientes foram incluídos. Notou-se correlação estatisticamente significativa entre a Pio 30 e 45 minutos após a instilação da ibopamina e a máxima pressão intra-ocular obtida na curva diurna ( $r=0,356, p=0,04$ e r $=0,429, p=0,01$, respectivamente). Entretanto, não foi observada correlação positiva com a flutuação diurna da pressão intra-ocular aos $30(\mathrm{r}=0,046, \mathrm{p}=0,8)$ e 45 minutos $(r=0,109, p=0,5)$. Conclusão: $O$ teste provocativo da ibopamina apresentou alta correlação com a pressão intraocular máxima na curva diurna em pacientes com glaucoma.
Entretanto, não foi notado relação linear direta com a flutuação diurna da pressão intra-ocular.

Descritores: Glaucoma; Soluções oftálmicas; Pressão intraocular; Agonistas de dopamina/uso diagnóstico; Ritmo circadiano; Estudo comparativo

\section{REFERENCES}

1. Armaly MF. Water-drinking test. I. Characteristics of the ocular pressure response and the effect of age. Arch Ophthalmol 1970;83(2):169-75.

2. Winder AF, Siddiqui AA, Donovan HC. Ocular hypertension and systemic responses to the water-drinking test. Br J Ophthalmol. 1978;62(6):414-9.

3. Spaeth GL. Effects of topical dexamethasone on intraocular pressure and the water drinking test. Arch Ophthalmol. 1966;76(6):772-83.

4. Harris LS, Galin MA. Cycloplegic provocative testing. Arch Ophthalmol. 1969;81(3):356-8.

5. Marchini G, Babighian S, Tosi R, Perfetti S, Bonomi L. Comparative study of the effects of $2 \%$ ibopamine, $10 \%$ phenylephrine, and $1 \%$ tropicamide on the anterior segment. Invest Ophthalmol Vis Sci 2003;44(1):281-9.

6. McLaren JW, Herman DC, Brubaker RF, Nau CB, Wayman LL, Ciarniello $\mathrm{MG}$, et al. Effect of ibopamine on aqueous humor production in normotensive humans. Invest Ophthalmol Vis Sci. 2003;44(11):4853-8.

7. Virno M, Taverniti L, De Gregorio F, Sedran L, Longo F. Increase in aqueous humor production following D1 receptors activation by means of ibopamine. Int Ophthalmol. 1996;20(1-3):141-6.

8. Magacho L, Lima FE, Costa ML, Fayad FA, Guimaraes NL, Avila MP. Ibopamine provocative test and glaucoma: Consideration of factors that may influence the examination. Curr Eye Res. 2004;28(3):189-93.

9. De Gregorio F, Pecori Giraldi J, Pannarale L, Saccucci S, Virno M. Ibopamine in glaucoma diagnostics: a new pharmacological provocative test. Int Ophthalmol. 1996;20(1-3):151-5.

10. Brogliatti B, Boles Carenini A, Bogetto C, Vadala G, Grignolo FM, Boles Carenini B. Ibopamine test in healthy and glaucomatous eyes: tonometric and pupillographic study. Acta Ophthalmol Scand Suppl. 2000;78(232):13-4.

11. Lima FE, Guimarães NLD, Santos LM, Costa LP, Ávila MP. Ibopamina tópica na propedêutica do glaucoma. Rev Bras Oftalmol. 2002;61(2):109-13.

12. Kitazawa Y, Horie T. Diurnal variation of intraocular pressure in primary openangle glaucoma. Am J Ophthalmol. 1975;79(4):557-66.

13. Sacca SC, Rolando M, Marletta A, Macri A, Cerqueti P, Ciurlo G. Fluctuations of intraocular pressure during the day in open-angle glaucoma, normal-tension glaucoma and normal subjects. Ophthalmologica. 1998;212(2):115-9.

14. David R, Zangwill L, Briscoe D, Dagan M, Yagev R, Yassur Y. Diurnal intraocular pressure variations: an analysis of 690 diurnal curves. $\mathrm{Br}$ J Ophthalmol. 1992;76(5):280-3.

15. Zeimer RC, Wilensky JT, Gieser DK, Viana MA. Association between intraocular pressure peaks and progression of visual field loss. Ophthalmology. 1991;98(1):64-9. Comment in: Ophthalmology. 1991;98(9):1323.

16. Asrani S, Zeimer R, Wilensky J, Gieser D, Vitale S, Lindenmuth K. Large diurnal fluctuations in intraocular pressure are an independent risk factor in patients with glaucoma. J Glaucoma. 2000;9(2):134-42. Comment in: J Glaucoma. 2000;9(6):487-8.

17. Anderson. DR, Patella VM. Automated static perimetry. 2nd ed. St. Louis, Missouri: Year Book Mosby; 1999.

18. The Advanced Glaucoma Intervention Study (AGIS): 7. The relationship between control of intraocular pressure and visual field deterioration. The AGIS Investigators. Am J Ophthalmol. 2000;130(4):429-40. Comment in: Am J Ophthalmol. 2000;130(4):490-1.

19. Armaly MF. The visual field defect and ocular pressure level in open angle glaucoma. Invest Ophthalmol. 1969;8(1):105-24.

20. The effectiveness of intraocular pressure reduction in the treatment of normaltension glaucoma. Collaborative Normal-Tension Glaucoma Study Group. Am J Ophthalmol. 1998;126(4):498-505. Comment in: Am J Ophthalmol. 1998;126 (4):578-81; Am J Ophthalmol. 1999;128(6):776-7; Am J Ophthalmol. 1999;127 (5):623-5; Am J Ophthalmol. 1999;127(5):625-6.

21. Ziai N, Dolan JW, Kacere RD, Brubaker RF. The effects on aqueous dynamics of PhXA41, a new prostaglandin F2 alpha analogue, after topical application in normal and ocular hypertensive human eyes. Arch Ophthalmol. 1993;111(10): 1351-8 